\title{
Comparison of Two Cleansing Pastes for the Removal of Biofilm from Dentures and Palatal Lesions in Patients with Atrophic Chronic Candidiasis
}

\author{
Marcela Cristina Damião ANDRUCIOLI ${ }^{1}$ \\ Leandro Dorigan de MACEDO $^{2}$ \\ Heitor PANZERI ${ }^{2}$ \\ Elza Helena Guimarães LARA ${ }^{3}$ \\ Helena de Freitas Oliveira PARANHOS ${ }^{2}$ \\ ${ }^{1}$ Private Dental Practice, Ribeirão Preto, SP, Brazil \\ ${ }^{2}$ Department of Dental Materials and Prosthesis, Faculty of Dentistry of Ribeirão Preto, University of São Paulo, \\ Ribeirão Preto, SP, Brazil \\ ${ }^{3}$ Department of Pharmaceutical Sciences, Faculty of Pharmacy of Ribeirão Preto, University of São Paulo, \\ Ribeirão Preto, SP, Brazil
}

\begin{abstract}
The efficacy of 2 oral hygiene products, an experimental toothpaste specific for complete denture cleansing and a regular standard toothpaste, was compared in terms of denture biofilm removal and cure of palatal lesions in patients with atrophic chronic candidiasis. The degree of correlation between presence of biofilm and mucosa erythema was also evaluated. Twenty-four complete denture wearers (45-80 years old) were divided into 2 groups: experimental paste and standard toothpaste (Sorriso-Kolynos, Brazil). Both groups received soft toothbrushes. The internal surfaces of upper dentures were stained using $1 \%$ sodium fluorescein and photographed at a $45^{\circ}$ angle at $0,15,30$ and 60 days. The slides were scanned and the areas of interest (denture total area and biofilm area) were measured (Image Tool software). The degree of erythema was evaluated on slides according to the Prosthesis Tissue Index. There was a significant reduction ( $1 \%$ ) in the degree of biofilm (ANOVA/Tukey) between the two initial visits ( 0 and 15 days) and the two final visits (30 and 60 days), and in the average erythema scores (Kruskal-Wallis) between 0 and 60 days, in both groups. The Mann-Whitney test showed a significant difference $(1 \%)$ between pastes in terms of biofilm degree, but no difference was found for the erythema score. Correlation values between biofilm and erythema degree were 0.3801 (experimental paste) and ( 0.3678 (standard toothpaste). We may therefore conclude that the experimental product was efficient for the removal of denture plaque biofilm.
\end{abstract}

Key Words: complete dentures, biofilm, denture cleansers, atrophic chronic candidiasis.

\section{INTRODUCTION}

Denture-induced stomatitis (atrophic chronic candidiasis) is an inflammatory lesion of the denturebearing mucosa that affects approximately $50 \%$ of patients wearing complete maxillary dentures (1) and has a multifactor etiology. Factors of particular significance are trauma caused by the denture itself, infection by Candida, poor denture hygiene, continuous denture wear, and dietary and systemic factors $(2,3)$.

Denture biofilm is an important etiologic factor for this disease. C. albicans and other species of fungus found in biofilm have been reported as important agents for the installation, maintenance and exacerbation of this disease.

Moreover, the colonization of oral surfaces, including denture-seating surfaces, could serve as a reservoir for disseminated infections, such as gastrointestinal infections. Furthermore, several studies indicate that pleuropulmonary infections may arise from aspiration of oral bacteria $(4,5)$. In addition, recent reports suggest the possibility that denture biofilm containing Candida sp may be a causative factor of caries and periodontitis on the abutment or on teeth adjacent to dentures (6).

The efficacy of several denture cleansers has

Correspondence: Profa. Dra. Helena de Freitas Oliveira Paranhos, Departamento de Materiais Dentários e Prótese, Faculdade de Odontologia de Ribeirão Preto, USP, Via do Café s/nº, 14040-904 Ribeirão Preto, SP, Brasil. Tel: +55-16-602-4006. e-mail: helenpar@forp.usp.br 
been clinically evaluated. Commercial denture cleansing products are generally not very efficient in denture biofilm control. The ideal product must be easy to handle, effective in the removal of organic and inorganic deposits, have antibacterial and antifungal properties, be non-toxic to humans, compatible with the denture materials, and also have a low cost (7).

The aim of this study was to evaluate the effectiveness of an experimental paste for complete denture cleansing compared to a standard toothpaste in patients with atrophic chronic candidiasis, in terms of denture biofilm removal and cure of palatal lesions.

\section{MATERIAL AND METHODS}

\section{Patient Selection and Instructions}

This study was carried out in 24 complete denture wearers (45-80 years of age) with atrophic chronic candidiasis. All patients had used dentures for 1 to 10 years. Patients were divided into 2 groups using a) standard toothpaste (Sorriso, Kolynos do Brasil, SP, Brazil); b) experimental product for denture cleansing (Faculty of Pharmacy of Ribeirão Preto, USP) (8,9). For both groups, soft bristle toothbrushes were supplied (Johnson \& Johnson, SP, Brazil). Subjects were instructed to brush their dentures 3 times a day, rinsing their mouth with water after brushing, and to keep the denture immersed in filtered water overnight. Patients received oral and denture hygiene orientation on the first visit (day 0) and were evaluated at 0, 15, 30 and 60 days.

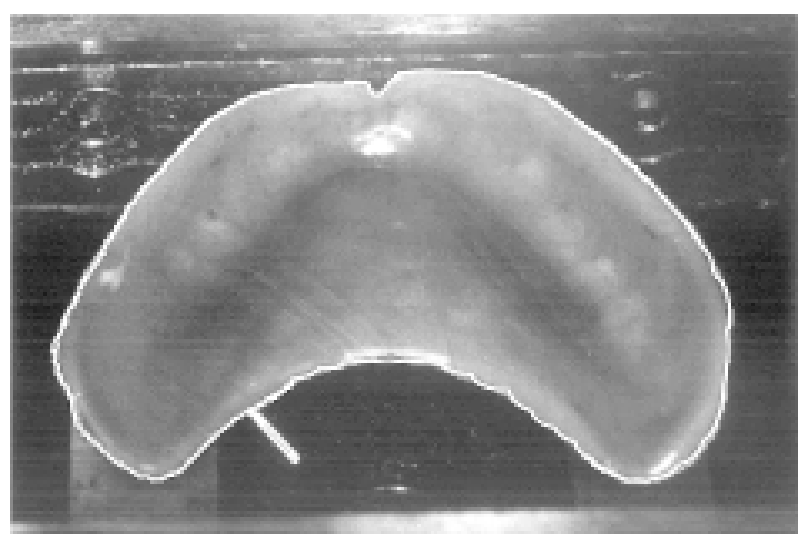

Figure 1. Photograph showing the delimitation of the external limits of the denture.

\section{Biofilm Quantification}

Biofilm was detected by applying $1 \%$ sodium fluorescein on the internal surface of the upper dentures for $30 \mathrm{~s}$ using a cotton swab. Dentures were then washed for $5 \mathrm{~s}$ and dried with air spray for $10 \mathrm{~s}$ before being photographed.

Dentures were positioned on a clamp (Morsa Universal Adriática S/A, SP, Brazil), with the intermediate shank at a $7^{\circ}$ angle, so that the internal surface of each denture was positioned at $45^{\circ}$ in relation to the worktable. The internal surface of the dentures was photographed using a camera (Canon EOS Elan II EQD, Canon Object. EF Macro $100 \mathrm{mmm} / 2: 8$, Canon Inc., Tokyo, Japan), a circular flash (Canon ML-3, Canon Inc., Tokyo, Japan), and slide films (Ektachrome Asa 100, Kodak Brasileira Comércio e Indústria, SP, Brazil) focused on the incisive papilla.

At each visit, a new photograph of the stained biofilm was taken and the biofilm was subsequently completely removed by brushing (hand brush, toothbrush and liquid soap).

Slides were scanned (CanoScan 2700F, Canon Inc., Tokyo, Japan) with 680 dpi resolution. The total area of each denture and the stained areas (biofilm) were measured (software Image Tool - Windows, 2.02). The external limits were measured to obtain the total area of each denture (Figure 1). For measurement of the biofilm-covered area, stained areas were delimited (Figure 2). Each stained area was measured separately and then the values were added. The percentage of biofilmcovered area for each denture was defined as the ratio

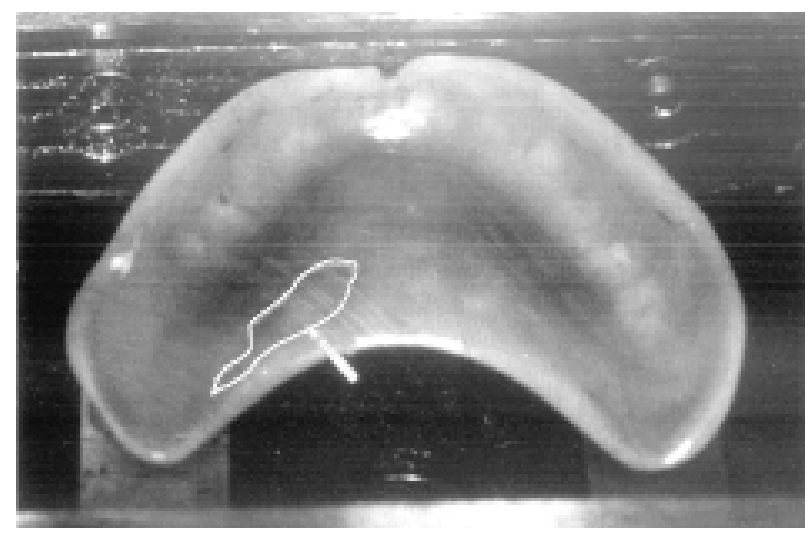

Figure 2. Photograph showing the delimitation of the stained area in the internal surface of the denture. 
between biofilm area and total internal surface area, multiplied by 100 .

\section{Palatal Lesion Cure}

Palatal mucosa was photographed (Ecktachrome

Table 1. Percentage of biofilm at $0,15,30$ and 60 days.

\begin{tabular}{|c|c|c|c|c|c|c|c|c|}
\hline \multirow[b]{2}{*}{ Patient } & \multicolumn{4}{|c|}{ Experimental toothpaste } & \multicolumn{4}{|c|}{ Standard toothpaste } \\
\hline & 0 days & 15 days & 30 days & 60 days & 0 days & 15 days & 30 days & 60 days \\
\hline 1 & 33.13 & 69.01 & 39.47 & 20.81 & 44.38 & 82.55 & 44.50 & 21.22 \\
\hline 2 & 16.16 & 81.24 & 68.22 & 20.54 & 1.53 & 85.55 & 19.61 & 3.65 \\
\hline 3 & 38.79 & 77.62 & 65.25 & 29.17 & 76.51 & 76.52 & 67.75 & 31.23 \\
\hline 4 & 59.53 & 78.51 & 38.68 & 7.59 & .68 & 68.51 & 24.55 & 10.33 \\
\hline 5 & 50.06 & 71.00 & 13.98 & 25.7 & 7.04 & 63.08 & 29.03 & 17.91 \\
\hline 6 & 34.65 & 46.67 & 6.74 & 23.61 & 7.58 & 93.90 & 38.56 & 22.54 \\
\hline 7 & 62.12 & 84.70 & 41.03 & 27.56 & 67.08 & 41.74 & 5.29 & 25.22 \\
\hline 8 & 75.58 & 66.90 & 36.15 & 14.66 & 74.57 & 55.92 & 45.58 & 30.87 \\
\hline 9 & 83.03 & 74.23 & 32.44 & 35.64 & 59.35 & 88.50 & 54.09 & 32.60 \\
\hline 10 & 31.39 & 32.83 & 17.57 & 27.54 & 84.31 & 58.09 & 62.31 & 72.90 \\
\hline 11 & 93.88 & 4.29 & 24.93 & 39.89 & 52.12 & 45.00 & 4.25 & 14.09 \\
\hline 12 & 79.20 & 10.53 & 14.45 & 48.15 & 4.12 & 40.03 & 47.43 & 89.38 \\
\hline & $58.13^{*}$ & $54.79 *$ & $33.24^{+}$ & $26.74^{+}$ & $66.62^{*}$ & $61.27^{*}$ & $36.91^{+}$ & $31.00^{+}$ \\
\hline \multicolumn{2}{|l|}{ Tukey test } & \multicolumn{3}{|c|}{23.56} & \multicolumn{4}{|c|}{23.58} \\
\hline
\end{tabular}

Same symbols showed statistically similar averages.

Table 2. Erythema scores according to the Prosthodontic Tissue Index.

\begin{tabular}{cccccccccc}
\hline & \multicolumn{3}{c}{ Experimental toothpaste } & & \multicolumn{5}{c}{ Standard toothpaste } \\
\cline { 2 - 3 } Patient & 0 days & 15 days & 30 days & 60 days & & 0 days & 15 days & 30 days & 60 days \\
\hline 1 & 2 & 1 & 2 & 2 & & 3 & 3 & 2 & 3 \\
2 & 2 & 0 & 0 & 0 & & 1 & 0 & 1 & 1 \\
3 & 3 & 3 & 3 & 2 & & 3 & 1 & 1 & 0 \\
4 & 2 & 2 & 1 & 0 & & 2 & 1 & 1 & 1 \\
5 & 2 & 1 & 1 & 2 & & 2 & 1 & 2 & 2 \\
6 & 1 & 1 & 1 & 0 & & 3 & 2 & 2 & 2 \\
7 & 3 & 2 & 3 & 2 & & 1 & 0 & 0 & 1 \\
8 & 2 & 2 & 2 & 2 & & 3 & 3 & 1 & 0 \\
9 & 3 & 2 & 1 & 1 & & 2 & 1 & 1 & 1 \\
10 & 2 & 2 & 1 & 1 & & 3 & 3 & 3 & 2 \\
11 & 3 & 3 & 3 & 2 & & 1 & 1 & 1 & 1 \\
12 & 3 & 2 & 1 & 0 & & 3 & 3 & 3 & 2 \\
\hline
\end{tabular}

$0=$ normal tissue, pink surface, with normal vascularization and aspect; $1=$ reddish inflamed mucosa, with areas of focal hyperemia, but generally normal aspect; 2 = reddish mucosa, with multiple hyperemic areas and widespread shiny surface; $3=$ markedly red mucosa, with or without focal hyperemia, shiny surface and granular inflammation.
ASA 100 - slide film) with the focus centered on the midpalatal raphe region. Slides were projected (10X) and the Prosthodontic Tissue Index (10) was applied: 0 $=$ normal tissue, pink surface, with normal vascularization and aspect; 1 = reddish inflamed mucosa, with areas of focal hyperemia, but generally normal aspect; 2 = reddish mucosa, with multiple hyperemic areas and widespread shiny surface; 3 = markedly red mucosa, with or without focal hyperemia, shiny surface and granular inflammation.

\section{RESULTS}

The biofilm percentage values are shown in Table 1. ANOVA showed statistically significant differences between visits $(p \leq 0.01)$. In order to clarify which paired averages were significantly different, Tukey test was used (Table 1). The KruskalWallis test also showed significant differences for erythema (Table 2) at $1 \%(\alpha=0.01-$ experimental cleansing paste $)$ and $5 \%(\alpha=0.05$ - standard toothpaste) between the $1^{\text {st }}$ and $4^{\text {th }}$ visit averages in both groups.

Comparison between the two pastes by the Mann-Whitney test showed statistically significant differences at $1 \%(\mathrm{U} 1=5$ - experimental product; $\mathrm{U} 2=11$ - standard toothpaste) for degree of biofilm and no statistically significant difference regarding erythema scores.

Correlation testing between biofilm (Table 1) and erythema scores (Table 2) resulted in values for $r=$ 0.3801 (experimental toothpaste) and $r=0.3678$ (standard toothpaste).

\section{DISCUSSION}

Denture biofilm is defined as a dense microbial layer comprising microorganisms and their metabolites, and it is known to contain more than $10^{11}$ organisms per gram of wet weight 
(6). In order to achieve its elimination, mechanical and chemical hygiene methods should be associated. However, mechanical procedures using toothbrush and paste are more commonly used (11). Chemical methods are not routinely applied, either due to lack of information or knowledge about these methods, cost, or due to lack of access or non-availability of these products on the market. When a mechanical hygiene procedure is indicated, it is important to recommend the use of specific products, avoiding those that are too abrasive, in order to prevent damage to the teeth or prosthesis base (12).

Among the methods of clinical evaluation of biofilm, staining is the most commonly used (7). It is associated to quantitative methods, or to a scoring methodology. Quantitative methods yield precise and objective results (13), and do not depend on skill or calibration of the operators. It is important to point out that variation between operators does exist, when a scoring system is used. Therefore, sectional observations should be proposed. A frequent limitation of attributing scores regarding presence of biofilm on the denture as a whole is the lack of consistency by the examiner for scoring. The operator frequently applies different criteria when giving scores to the local biofilm concentrations (14). In this study, a computerized quantitative method associated with photographs was used, due to the known difficulties of biofilm quantification by visual inspection alone (15). In order to improve visualization, photographs were taken at a $45^{\circ}$ angle. This computerized method can eliminate the need for a scanner, by connecting a digital camera directly to the computer (16).

Sodium fluorescein was the staining agent chosen, due to its affinity with biofilm, being easy to remove and harmless to the prosthesis (17). A highquality soft bristle toothbrush was used, in order to effectively remove the biofilm, causing no damage to the acrylic resin. Subjects were advised to brush the prosthesis when they woke up, since the recommendation of keeping the denture in a glass of filtered water is not always followed. Pastes specific for denture cleansing, which could allow comparison between similar products, are not available in Brazil. Moreover, standard toothpastes are the oral hygiene products commonly used by wearers of complete dentures.

According to the results for both pastes, the biofilm levels were high before the hygiene products were supplied ( $1^{\text {st }}$ visit) and at the $2^{\text {nd }}$ visit in both groups. Even though the products were being used 3 times a day, the decrease in biofilm was not significant between the $1^{\text {st }}$ and the $2^{\text {nd }}$ visits. For every subsequent interval between visits, however, a statistically significant drop in the levels of biofilm was observed (Table 1). An important fact to be noted is the statistical difference between biofilm averages when the experimental paste was compared to the standard toothpaste (Mann-Whitney test). Laboratory evaluation of the experimental paste (9) demonstrated, among other features, a formulation with optimum consistency that was mild and had adequate viscosity. The abrasive (mildly abrasive silica) in the product allows a slight mechanical cleansing action, while the surfactants (Hergaterg, cetylpyridinium chloride, sulfamic and benzoic acids), at relatively high concentrations, present a cleansing and degreasing effect. Besides the abrasive and surfactant agents, the product also includes antiseptic substances, which complement each other's actions. Even using a soft bristle toothbrush, the product effectively cleaned the prosthetic device, with no harm to any of its components.

In regard to the degree of stomatitis, there was a significant reduction from the $1^{\text {st }}$ to the $4^{\text {th }}$ visits, not taking into account the statistical difference between both pastes (Mann-Whitney test). Correlation between percentages of biofilm and erythema scores showed low values $(r=0.3801$ for the experimental paste, and $\mathrm{r}=0.3678$ for the standard paste), suggesting that a decrease in the amount of biofilm is not necessarily followed by a decrease in the degree of erythema. This result is in accordance with others studies $(11,18,19)$ that found no relationship between tissue inflammation and degree of denture biofilm.

We conclude that the use of a mechanical method with the experimental paste plus a soft-bristle toothbrush was effective in the control the biofilm in complete dentures and for promoting oral health in complete prosthesis wearers and that there was no correlation between percentages of biofilm and erythema.

\section{RESUMO}

Foram comparadas duas pastas, específica para prótese total e convencional para dentes naturais, quanto à habilidade de remoção de biofilme e cura de lesões do palato em pacientes com Candidíase Atrófica Crônica. Avaliou-se também o grau de correlação entre biofilme e grau de eritema. Vinte e quatro pacientes (45-80 anos) foram distribuídos em: a) pasta específica (produto experimental); b) pasta convencional (pasta dental Sorriso). Para ambos os grupos foram fornecidas escovas dentais de cerdas macias. As 
superfícies internas (próteses superiores) foram evidenciadas (fluoresceína $1 \%$ ) e fotografadas $\left(45^{\circ}\right)$ em 4 visitas $(0,15,30$ e 60 dias). Os slides foram escaneados e as áreas (total e biofilme) foram medidas (software Image Tool). Sobre slides avaliou-se o grau de eritema empregando-se o Índice Tecidual de Prótese. Houve redução significativa (1\%) dos níveis de biofilme (análise de variância) entre as primeiras ( 0 e 15 dias) e últimas visitas (45 e 60 dias) e dos escores de eritema (Kruskal-Wallis) da primeira para quarta vistita para ambas pastas. O teste de Mann-Whitney mostrou diferença estatística entre as pastas para os níveis de biofilme e igualdade estatística para os escores de eritema. Os valores de correlação entre níveis de biofilme e grau de eritema foram de 0,3801 (pasta específica) e 0,3678 (pasta convencional). A pasta específica mostrou-se efetiva, mostrando que é possível a manutenção da higiene de próteses totais com o uso regular de higienizador em forma de pasta.

\section{ACKNOWLEDGEMENTS}

We are indebted to FAPESP, Brazil, for its financial support of this project.

\section{REFERENCES}

1. Wilson J. The aetiology, diagnosis and management of denture stomatitis. Brit Dent J 1998;185:380-384.

2. Lombardi T, Budtz-Jørgensen E. Treatment of denture-induced stomatitis: a review. Eur J Prosthodont Restor Dent 1993;2:1722.

3. Webb BC, Thomas CJ, Willcox MDP, Harty DWS, Knox KW. Candida-associated denture stomatitis. Aetiology and management: A review. Part 2. Oral diseases caused by Candida species. Aust Dent J 1998;43:160-166.

4. Green SL. Anaerobic pleuro-pulmonary infections. Post Grad Med 1979;65:62-66.

5. Martin BJ, Corlew MM, Wood H, Olson D, Golopol LA, Wingo $\mathrm{M}$, Kirmani N. The association of swallowing dysfunction and aspiration pneumonia. Dysphagia 1994;9:1-6.

6. Nikawa H, Hamada T, Yamamoto T. Denture plaque - past and recent concerns. J Dent 1998;26:299-304.

7. Nikawa H, Hamada T, Yamashiro H, Kumagai H. A review of in vitro and in vivo methods to evaluate the efficacy of denture cleansers. Int J Prosthod 1999;12:153-159.

8. Paranhos HFO, Lara EHG, Panzeri H, Candido RC, Ito IY. Capacity of denture plaque removal and antimicrobial action of a specific paste formulated for denture cleaning. Braz Dent $J$ 2000;11:97-104.

9. Paranhos HFO, Lara EHG, Pardini LC, Ito IY, Panzeri H. Evaluación (en laboratorio y clínica) de una pasta específica para higienización de dentaduras completas. Rev Fola Oral 2000;6:7682.

10. Bloem TJ, Razzog ME. An index for the assessment of oral health status in the edentulous population. Spec Care Dent 1982;3:121124.

11. Kulak-Ozkan Y, Kazazolu E, Arikan A. Oral hygiene habits, denture cleanliness, presence of yeasts and stomatitis in elderly people. J Oral Rehabil 2002;29:300-304.

12. Dyer D, MacDonal E, Newcombe RG, Scratcher C, Ley F, Addy M. Abrasion and stain removal by different manual toothbrushes and brush action: studies in vitro. J Clin Periodontol 2001;28:121127.

13. Fernandes RAG, Zaniquelli O, Paranhos HFO. Análise dos métodos de contagem de pontos e planímetro na quantificação do biofilme da dentadura - um estudo de validação metodológica. Pesqui Odontol Brás 2002;16:63-68.

14. McCabe JF, Murray ID, Laurie J, Kelly PJ. A method for scoring denture plaque. Eur J Prosthodont Restor Dent 1996;4:59-64.

15. Ambjørnsen E, Rise J, Haugejorden O. A study of examiner errors associated with measurement of denture plaque. Acta Odontol Scand 1984;42:183-191.

16. Sheen SR, Harrison A. Assessment of plaque prevention on dentures using an experimental cleanser. J Prosthet Dent 2000;84:594-601.

17. Silva CHL, Paranhos HFO, Ito IY. Evidenciadores de biofilme em prótese total: avaliação clínica e antimicrobiana. Pesqui Odontol Brás 2002;16:270-275.

18. Tarbet WJ. Denture plaque: Quiet destroyer. J Prosthet Dent 1982;48:647-652.

19. Chamberlain BB, Bernier SH, Bloeh TJ, Razooc ME. Denture plaque control and inflammation in the edentulous patient. $\mathrm{J}$ Prosthet Dent 1985;54:78-81. 